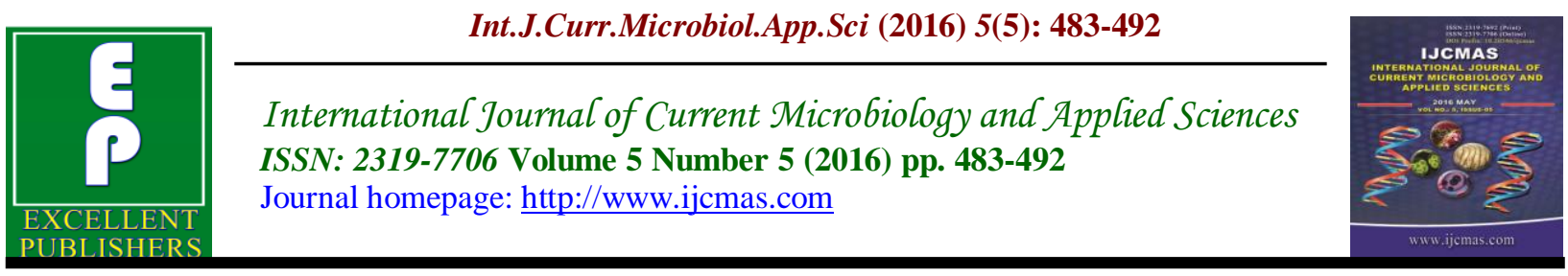

Original Research Article

http://dx.doi.org/10.20546/ijcmas.2016.505.050

\title{
Citric Acid Production from Different Sources under Submerged Conditions using Aspergillus niger
}

\author{
Pallavi Singh ${ }^{1 *}$, Sadiya Draboo², Aishwarya Singh $^{2}$, Swapnil Chaturvedi², $^{2}$ \\ Swati Sharma ${ }^{2}$ and Pooja Verma ${ }^{2}$ \\ ${ }^{1}$ Associate Professor, Department of Biotechnology, IILM Academy of Higher Learning, India \\ ${ }^{2}$ Undergraduate students (4th year), Department of Biotechnology, IILM Academy of Higher \\ Learning, India \\ *Corresponding author
}

Keywords Citric acid, Aspergillusniger, Submerged fermentation, Czapek dox, Cane molasses, Orange peel, titration, Optical density, $\mathrm{pH}$ and temperature.

\begin{tabular}{l}
\hline Article Info \\
\hline Accepted: \\
18 April 2016 \\
Available Online: \\
10 May 2016
\end{tabular}

\section{A B S T R A C T}

Extensive developments in the area of industrial biotechnology over past few years have signified the importance of citric acid as one of the most known organic acid, applied mainly as flavoring, emulsifying, cleaning, and chelating agent. It also plays a major role in pharmaceutical and cosmetic industries. Citric acid is produced by various microorganisms such as Aspergillus niger, Penicillium restrictum, Trichoderma viride, Mucor piriformis, A. awamori. A. niger is one of the most commonly used source for citric acid production under submerged fermentation conditions. A.niger was isolated from rotten onion, coconut, and lemon and was grown in supplemented Potato Dextrose Broth (PDB) at $30^{\circ} \mathrm{C}$ for 7 days. Best source for isolation of A.niger amongst these sources was analyzed by observation of optical density. Subsequently, production of citric acid using A.Niger on variable sugar sources was carried under Nitrogen and phosphorus limitation. Three different production media for citric acid production were used,Cane Molasses, Czapek Dox and Orange peel media. Effect of variation of $\mathrm{pH}$ in the range of 1-5 and temperature in the range of 200 to $500 \mathrm{C}$ over production of citric acid in cane molasses, Czapek Dox and Orange peel was estimated. Quantitative estimation of citric acid produced under varying environmental parameters in submerged culture condition was done using titration method and it was observed the best production media for citric acid production using A.nigerwas Cane molasses media at the $\mathrm{pH} 1$ and temperature $20^{\circ} \mathrm{C}$.

\section{Introduction}

Citric acid i.e. 3-carboxy-3-hydroxy pentane-1-5-dioic acid (C6H8O7) is a weak organic acid found naturally in citrus fruits such as limes, oranges, berries, tangerines, and grape fruits. It is an intermediate compound formed in Kreb'scycle (TCA Cycle) and is a common metabolite in all aerobic organisms. Industrially, citric acid is produced by submerged fermentation. The first industrial production of citric acid began in 1890 by Italian Citrus Fruit industry, calcium citrate was precipitated by treating the juice with calcium hydroxide (hydrated lime), then this calcium citrate 
was converted to citric acid using sulfuric acid. Two forms of citric acid have been observed, one is anhydrous form (water-free form) and other is monohydrate form. The later can be converted to anhydrous form at $78^{\circ} \mathrm{C}$.Millions of tons of citric acid is produced per year. Dominant use of citric acid is mainly in food $(70 \%)$, in pharmaceuticals $(12 \%)$, others $(18 \%)$, (Tran et al., 1998; Wang 1998; Ates et al., 2002). According to recent studies and developments citric acid based polymers have been created with enhanced mechanical properties used in the development of biodegradable elastomers which has been increasingly important for tissue engineering, for culturing variety of cells, in many biomedical applications and in drug delivery (Richard T. Tran, Yi Zhang, DipendraGyawali and Jian Yiang, 2009). Common applications of citric acid is as flavor enhancers, preservatives, as chelating and emulsifying agent. It is also a common constituent in kitchen cleaning solutions. In military, citric acid is used for efficient removal of post soldering flux residues (Robin et al., 1995; Ashkan et al., 2010; Guillermo et al., 2010).

Citric acid is produced by various microorganisms such as Aspergillus niger, Penicillium restrictum, Trichoderma viride, Mucor piriformis, A. awamori, but production of citric acid by $A$. nigeris one of the most commonly used organism using submerged fermentation. A.niger is generally considered as a asexual organism but, sexually reproducing spores also have been found hence it is classified in class Deuteromycetes, it belongs to the phylum Ascomycota, class Eurtiomycetes, order of Eurotiales, family of Trichocomacae and genus Aspergillus. Morphologically, it appears black long conidiophores with globose at the tip. Being ubiquitous in nature it can grow on diverse habitats such as rotten vegetables and fruits, soil and plant debris and can be identified by producing colonies with carbon black conidia. The advantage of A. niger over other citric acid producing microorganisms is that it can grow on nutrient depleted media, it is thermo-tolerant to low temperatures and gives high yield. Recent research concluded that by increasing the spore count from 104 to 109 spores per $\mathrm{ml}$ as inoculum results in the bigger A.niger cells that can be used for enzymatic production of chitosan (Javedchehri, 2013).

Countries like Brazil, Bangladesh import citric acid from other countries and due to its extensive use in day to day life its demand is increasing. Citric acid can be produced chemically but production by microbial fermentation has proven to be a better option (Mattey, 1992). Studies reveal mutant strains of $A$. niger (GCBT7) shows hyperproducibility of citric acid without supplements (Sikander Ali, Ikram-ul-haq, Qadeer, Javed Iqbal, 2002). Keeping in view, the advantage of biological fermentation over chemical synthesis we had choosen three media Czapek dox, orange peel, and cane molasses media. More than one substrate used for fermentative media had been proven to be best for citric acid production (Laboni Majumder et al., 2010).

The objective of this study was to identify the best source for isolating the Aspergillus niger, Assess the impact of different environmental conditions i.e. temperature and $\mathrm{pH}$ on citric acid production and, estimate the best production media for citric acid production using $A$. niger.

\section{Materials and Methods}

Isolation of Aspergillus niger: Potato Dextrose Broth(PDB) was prepared by dissolving $7.2 \mathrm{~g}$ of PDB in $300 \mathrm{ml}$ of distilled water and was autoclaved at $121^{\circ} \mathrm{C}$ 
for 20 minutes. Further PDB media was divided equally into 3 flasks. A. niger was isolated from three different sources, rotten coconut, onion, and lemonon PDB media by inoculating $1 \mathrm{gm}$ of each source. Inoculated samples were kept at $30^{\circ} \mathrm{C}$ for 7 days at 80 rpm in orbital shaker for incubation. Growth of A. niger was analyzed by measuring Optical density at 580nm in spectrophotometer.

Plating was done to obtain colonies of $A$. niger using Czapek Dox agar. Six plates were prepared, two for each sample. Streaking was done and plates were maintained at $30^{\circ} \mathrm{C}$ for 5 days in B.O.D. incubator. Maximum growth was observed in plates streaked with onion sample, hence concluded onion is the best source for $A$. niger isolation. Seed culture was prepared by taking the colonies from plate streaked with onion sample in $200 \mathrm{ml}$ of distilled water with $4.8 \mathrm{~g}$ of PDB and was kept in orbital shaker at $30^{\circ} \mathrm{C}$ for 2 days for acclimatization.

Substrate used: (a) Czapek dox broth (b) Cane molasses (c) Orange peels

Pre-treatment of substrate and preparation of media:

\section{Orange Peel Media}

Orange peels were washed with tap water, cut in small pieces and dried in oven at $60^{\circ} \mathrm{C}$ for overnight. The substrate was powdered by using a mortar pestle and then sieved. Dried powder of orange peel $(150 \mathrm{~g})$ was mixed with $150 \mathrm{~g}$ glucose, $150 \mathrm{~g}$ sucrose, $2.5 \mathrm{~g} \quad \mathrm{NH} 4 \mathrm{NO} 3, \quad 5 \mathrm{~g}$ (NH4)3PO4, $0.25 \mathrm{~g} / \mathrm{l}$ $\mathrm{MgSO} 4.7 \mathrm{H} 2 \mathrm{O}$ in $1000 \mathrm{ml}$ of distilled water. This 1 liter solution was equally divided into 5 flasks each containing $200 \mathrm{ml}$ of solution and $\mathrm{pH}$ was varied from 1 to 5 . All the flasks were then autoclaved.

\section{Cane Molasses Media}

Cane molasses media was prepared by boiling 5-6 glasses of sugarcane juice for few hours and was concentrated to $100 \mathrm{ml}$ solution. $35 \mathrm{ml}$ of $1 \mathrm{~N} \mathrm{H} 2 \mathrm{SO} 4$ and $900 \mathrm{ml}$ of distilled water was added to $100 \mathrm{ml}$ of the solution to make the solution volume upto $1000 \mathrm{ml}$.This solution was again boiled for half an hour. After cooling, solution was neutralized with calcium oxide and kept overnight. Clear supernatant liquid $(800 \mathrm{ml})$ was pipette out and addition of distilled water $(200 \mathrm{ml})$ was done to make the volume upto $1000 \mathrm{ml}$.Further addition of NH4NO3 2.5g, (NH4)3PO4 5g, MgSO4.7H2O 0.25 $\mathrm{g} / \mathrm{l}$ to solution.. This 1litre solution was equally divided into 5 flasks each containing $200 \mathrm{ml}$ of solution with variation in $\mathrm{pH}$ ranging from 1 to 5 and then all flasks were autoclaved.

\section{Czapek Dox Media}

Czapek dox broth was prepared by addition of NaNO3 3g, K2HPO4 $1 \mathrm{~g}, \mathrm{MgSO} 4.7 \mathrm{H} 2 \mathrm{O}$ $0.5 \mathrm{~g}, \mathrm{KCl} 0.5 \mathrm{~g}, \mathrm{FeSO} 40.01 \mathrm{~g}$, Sucrose $30 \mathrm{~g}$ in $1000 \mathrm{ml}$ of distilled water and $\mathrm{pH}$ variation ( 1 to 5 ) was done by dividing 1 liter solution equally into 5 flasks containing $200 \mathrm{ml}$ each and then autoclaved.

\section{Inoculation and Incubation}

Cane molasses media with $\mathrm{pH}=1$ (200ml) was further subdivided into 4 flasks each containing $50 \mathrm{ml}$ media were inoculated with seed culture $(2 \mathrm{ml})$ each and all 4 flasks were kept at different temperatures i.e. $20^{\circ} \mathrm{C}$, $30^{\circ} \mathrm{C}, 40^{\circ} \mathrm{C}$, and $50^{\circ} \mathrm{C}$ in different incubators for 12 days. Same was done for $\mathrm{pH} 2, \mathrm{pH} 3, \mathrm{pH} 4$ and $\mathrm{pH}$ 5. Similar procedure was applied to other two, Czapek dox and Orange peel media. 


\section{Estimation method}

Mycelial wet weight was determined using filtration and centrifugation method and mycelial mat was kept in oven for overnight at $70^{\circ} \mathrm{C}$ to determine the dry weight also.

\section{Citric acid Estimation}

Estimation of citric acid was done by titration method by using $0.1 \mathrm{~N} \mathrm{NaOH}$ for cane molasses and czapek dox and $1 \mathrm{~N}$ $\mathrm{NaOH}$ for Orange peel media with phenolphthalein as indicator.

$\%$ citric acid was calculated by using following formula:

$\%$ citric acid $=\mathrm{N} \times \mathrm{V} 1 \times \mathrm{EqWt} / \mathrm{V} 2 \times 10$

where;

$\mathrm{N}=$ Normality of $\mathrm{NaOH}$ solution

$\mathrm{V} 1=$ Volume of $0.1 \mathrm{~N} \mathrm{NaOH}$ for cane molasses and czapek dox / Volume of $1 \mathrm{~N} \mathrm{NaOH}$ for orange peel media.

EqWt. = Equivalent weight of citric acid.

$\mathrm{V} 2=$ Volume of sample $(\mathrm{ml})$

\section{Results and Discussion}

After isolation of A.niger on PDB media, maximum optical density was observed on Onion i.e. 1.6, however, it was close to growth on Lemon, optical density being 1.5. Minimum optical density was observed on Coconut sample. It indicates that Onion and Lemon are the best sources to extract and isolate A.niger under temperature conditions of $30^{\circ} \mathrm{C}$. However, V. Maharani (et al 2014) have reported spoiled coconut is prominent source for A.niger at $\mathrm{pH} 3.5$ and temperature $30^{\circ} \mathrm{C}$.

As per the estimation of wet weight of A.niger on cane molasses media, Best growth is observed at $\mathrm{pH} \mathrm{2,} \mathrm{temperature}$ $30^{\circ} \mathrm{C}$. The growth was observed around $5.04 \mathrm{~g}$, and minimum was observed at $\mathrm{pH} 3$ and temperature $50^{\circ} \mathrm{C}$. While, the estimation of wet weight of A.niger on orange peel media revealed, best growth at $\mathrm{pH} 1$ and temperature $40^{\circ} \mathrm{C}$, where the growth was around $5.46 \mathrm{~g}$, and minimum growth was observed at $\mathrm{pH} 5$, temperature $50^{\circ} \mathrm{C}$. Calculation of wet weight of A.niger on Czapek dox media indicated the best growth at $\mathrm{pH} 5$ and temperature $20^{\circ} \mathrm{C}$, being $8.127 \mathrm{~g}$, whereas the minimum growth was observed at $\mathrm{pH} 5$ and temperature $50^{\circ} \mathrm{C}$.

As per the observation related to the \% production of citric acid on Cane Molasses media, the highest amount was detected at $\mathrm{pH} 1$, Temperature $20^{\circ} \mathrm{C}$, being $51.6 \%$, whereas the lowest being estimated at $\mathrm{pH} 1$ and temperature $40^{\circ} \mathrm{C}$. Calculations show the maximum production of citric acid on Orange peel media was observed at $\mathrm{pH} 1$ and temperature $30^{\circ} \mathrm{C}$ being $51 \%$, and the lowest was recorded at $\mathrm{pH} 4$, temperature $30^{\circ} \mathrm{C}$. While, Czapek dox media indicated the highest citric acid production to be at $\mathrm{pH}$ 1 and temperature $50^{\circ} \mathrm{C}$, being $19.5 \%$, whereas the lowest being estimated at $\mathrm{pH} 1$ temperature $30^{\circ} \mathrm{C}$.

Table.1 Optical Density of A.niger on Different Sources:

\begin{tabular}{|l|c|}
\hline Sample & O.D. (580nm) \\
\hline Coconut & 1.17 \\
\hline Lemon & 1.5 \\
\hline Onion & 1.6 \\
\hline
\end{tabular}


Table.2 Biomass of A.niger on Cane Molasses Media at varying $\mathrm{pH}$ and Temperature

\begin{tabular}{|c|c|c|c|}
\hline pH & Temp $\left({ }^{\circ} \mathbf{C}\right)$ & Wet wt. $(\mathbf{g})$ & Dry wt.(g) \\
\hline \multirow{4}{*}{1} & 20 & 3.706 & 0.223 \\
\cline { 2 - 4 } & 30 & 3.390 & 0.297 \\
\cline { 2 - 4 } & 40 & 0.101 & 0.393 \\
\hline \multirow{4}{*}{2} & 50 & 0.716 & 0.300 \\
\cline { 2 - 4 } & 20 & 1.024 & 0.352 \\
\cline { 2 - 4 } & 30 & 5.041 & 0.413 \\
\hline \multirow{4}{*}{3} & 40 & 4.382 & 0.470 \\
\cline { 2 - 4 } & 50 & 0.985 & 0.327 \\
\cline { 2 - 4 } & 20 & 1.897 & 0.367 \\
\cline { 2 - 4 } & 30 & 2.430 & 0.390 \\
\hline \multirow{4}{*}{4} & 40 & 2.536 & 0.477 \\
\cline { 2 - 4 } & 50 & 0.060 & 0.023 \\
\cline { 2 - 4 } & 20 & 2.839 & 0.543 \\
\hline \multirow{4}{*}{5} & 30 & 3.930 & 0.252 \\
\cline { 2 - 4 } & 40 & 1.900 & 0.047 \\
\cline { 2 - 4 } & 50 & 0.607 & 0.334 \\
\cline { 2 - 4 } & 20 & 2.930 & 0.018 \\
\hline
\end{tabular}

Table.3 Biomass of A.niger on Czapek Dox Media at varying $\mathrm{pH}$ and Temperature

\begin{tabular}{|c|c|c|c|}
\hline pH & Temp $\left({ }^{\circ} \mathbf{C}\right)$ & Wet wt. $(\mathbf{g})$ & Dry wt.(g) \\
\hline \multirow{4}{*}{1} & 20 & 0.049 & 0.009 \\
\cline { 2 - 4 } & 30 & 5.620 & 0.489 \\
\cline { 2 - 4 } & 40 & 0.061 & 0.013 \\
\cline { 2 - 4 } & 50 & 0.023 & 0.000 \\
\hline \multirow{4}{*}{2} & 20 & 3.657 & 0.451 \\
\cline { 2 - 4 } & 30 & 4.480 & 0.344 \\
\cline { 2 - 4 } & 40 & 3.334 & 0.316 \\
\hline \multirow{4}{*}{3} & 50 & 0.025 & 0.000 \\
\cline { 2 - 4 } & 20 & 4.643 & 0.442 \\
\cline { 2 - 4 } & 30 & 6.360 & 0.244 \\
\hline \multirow{4}{*}{4} & 40 & 5.704 & 0.282 \\
\cline { 2 - 4 } & 50 & 0.310 & 0.000 \\
\cline { 2 - 4 } & 20 & 3.952 & 0.461 \\
\cline { 2 - 4 } & 30 & 5.421 & 0.285 \\
\hline \multirow{4}{*}{5} & 40 & 4.801 & 0.340 \\
\cline { 2 - 4 } & 50 & 0.021 & 0.000 \\
\cline { 2 - 4 } & 20 & 8.127 & 0.684 \\
\cline { 2 - 4 } & 30 & 5.850 & 0.309 \\
\hline
\end{tabular}


Table.4 Biomass of A.niger on Orange Peel Media at varying $\mathrm{pH}$ and Temperature

\begin{tabular}{|c|c|c|c|}
\hline pH & Temp $\left({ }^{\circ} \mathbf{C}\right)$ & Wet wt. (g) & Dry wt.(g) \\
\hline \multirow{4}{*}{1} & 20 & 3.340 & 0.546 \\
\cline { 2 - 4 } & 30 & 3.482 & 0.849 \\
\cline { 2 - 4 } & 40 & 5.460 & 0.933 \\
\cline { 2 - 4 } & 50 & 3.005 & 0.907 \\
\hline \multirow{4}{*}{2} & 20 & 2.035 & 0.387 \\
\cline { 2 - 4 } & 30 & 3.573 & 0.384 \\
\cline { 2 - 4 } & 40 & 1.167 & 0.304 \\
\cline { 2 - 4 } & 50 & 3.300 & 0.674 \\
\cline { 2 - 4 } & 20 & 2.547 & 0.300 \\
\cline { 2 - 4 } & 30 & 2.130 & 0.420 \\
\cline { 2 - 4 } & 40 & 3.458 & 0.759 \\
\hline \multirow{4}{*}{4} & 50 & 0.923 & 0.377 \\
\cline { 2 - 4 } & 20 & 2.677 & 0.520 \\
\cline { 2 - 4 } & 30 & 2.219 & 0.672 \\
\cline { 2 - 4 } & 40 & 2.207 & 0.720 \\
\hline \multirow{3}{*}{5} & 50 & 1.868 & 0.906 \\
\cline { 2 - 4 } & 30 & 3.822 & 0.559 \\
\cline { 2 - 4 } & 40 & 3.204 & 0.515 \\
\cline { 2 - 4 } & 50 & 2.259 & 0.358 \\
\hline
\end{tabular}

Fig.1 \% Citric Acid production on Cane molasses Media

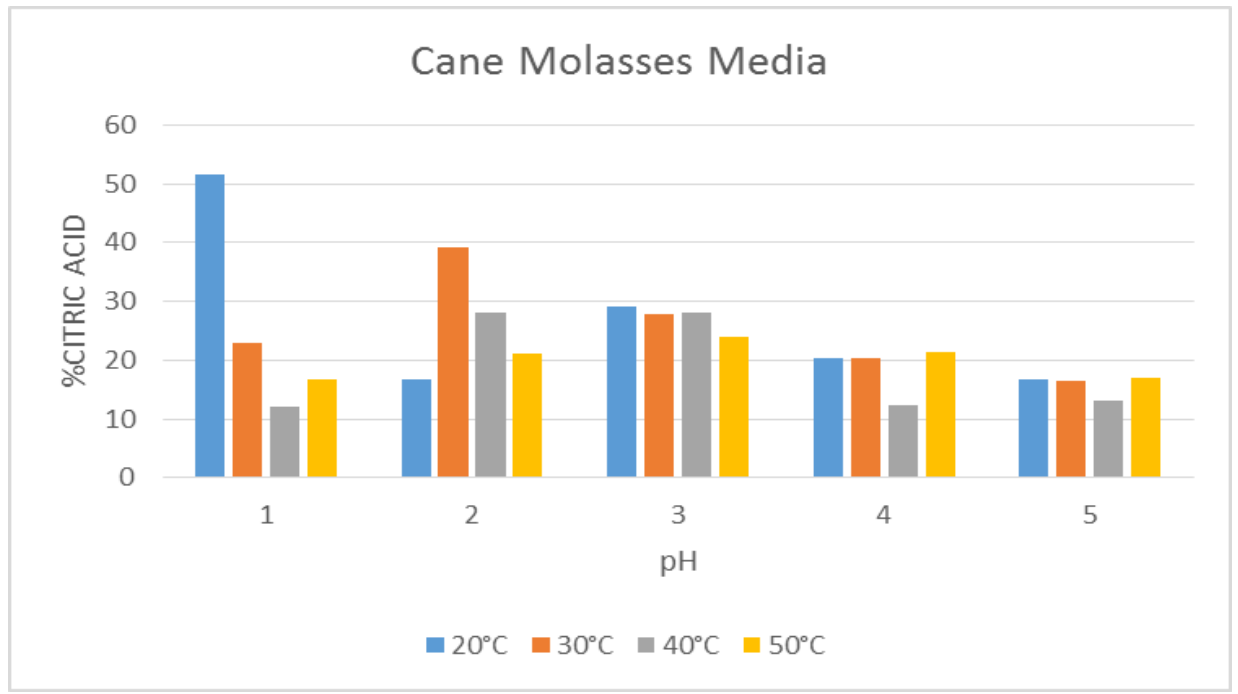


Table.5 \% Citric Acid produced on Cane Molasses Media at Variable pH and Temperature.

\begin{tabular}{|c|c|c|c|}
\hline Media & pH & $\operatorname{Temp}\left({ }^{\circ} \mathrm{C}\right)$ & $\% \operatorname{acid}(w / v)$ \\
\hline \multirow{20}{*}{$\begin{array}{c}\text { Cane } \\
\text { Molasses } \\
\text { Media }\end{array}$} & \multirow{4}{*}{1} & 20 & 51.6 \\
\hline & & 30 & 22.8 \\
\hline & & 40 & 12.0 \\
\hline & & 50 & 16.8 \\
\hline & \multirow{4}{*}{2} & 20 & 16.8 \\
\hline & & 30 & 39.2 \\
\hline & & 40 & 28.2 \\
\hline & & 50 & 21.0 \\
\hline & \multirow{4}{*}{3} & 20 & 29.1 \\
\hline & & 30 & 27.9 \\
\hline & & 40 & 28.2 \\
\hline & & 50 & 24.0 \\
\hline & \multirow{4}{*}{4} & 20 & 20.4 \\
\hline & & 30 & 20.4 \\
\hline & & 40 & 12.3 \\
\hline & & 50 & 21.3 \\
\hline & \multirow{4}{*}{5} & 20 & 16.8 \\
\hline & & 30 & 16.4 \\
\hline & & 40 & 13.2 \\
\hline & & 50 & 17.1 \\
\hline
\end{tabular}

Fig. $\%$ Citric Acid production on Czapek dox Media

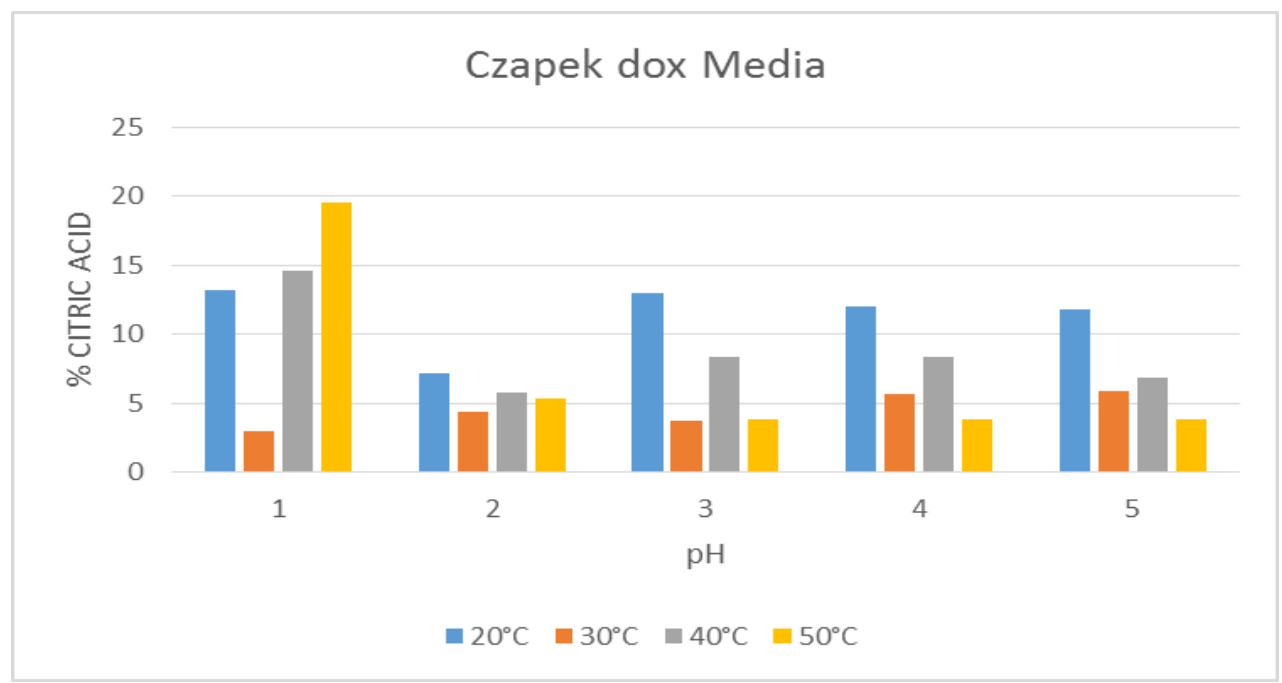


Table.6 \% Citric Acid produced on Orange Peel Media at variable $\mathrm{pH}$ and Temperature.

\begin{tabular}{|c|c|c|c|}
\hline Media & pH & $\operatorname{Temp}\left({ }^{\circ} \mathrm{C}\right)$ & $\% \operatorname{acid}(w / v)$ \\
\hline \multirow{20}{*}{$\begin{array}{c}\text { Orange Peel } \\
\text { Media }\end{array}$} & \multirow{4}{*}{1} & 20 & 24.0 \\
\hline & & 30 & 51.0 \\
\hline & & 40 & 27.0 \\
\hline & & 50 & 30.0 \\
\hline & \multirow{4}{*}{2} & 20 & 18.0 \\
\hline & & 30 & 18.0 \\
\hline & & 40 & 24.0 \\
\hline & & 50 & 30.0 \\
\hline & \multirow{4}{*}{3} & 20 & 3.0 \\
\hline & & 30 & 24.0 \\
\hline & & 40 & 27.0 \\
\hline & & 50 & 30.0 \\
\hline & \multirow{4}{*}{4} & 20 & 21.0 \\
\hline & & 30 & 15.0 \\
\hline & & 40 & 17.0 \\
\hline & & 50 & 24.0 \\
\hline & \multirow{4}{*}{5} & 20 & 21.6 \\
\hline & & 30 & 24.0 \\
\hline & & 40 & 22.8 \\
\hline & & 50 & 34.2 \\
\hline
\end{tabular}

Fig.3 \% Citric Acid production on Orange Peel Media

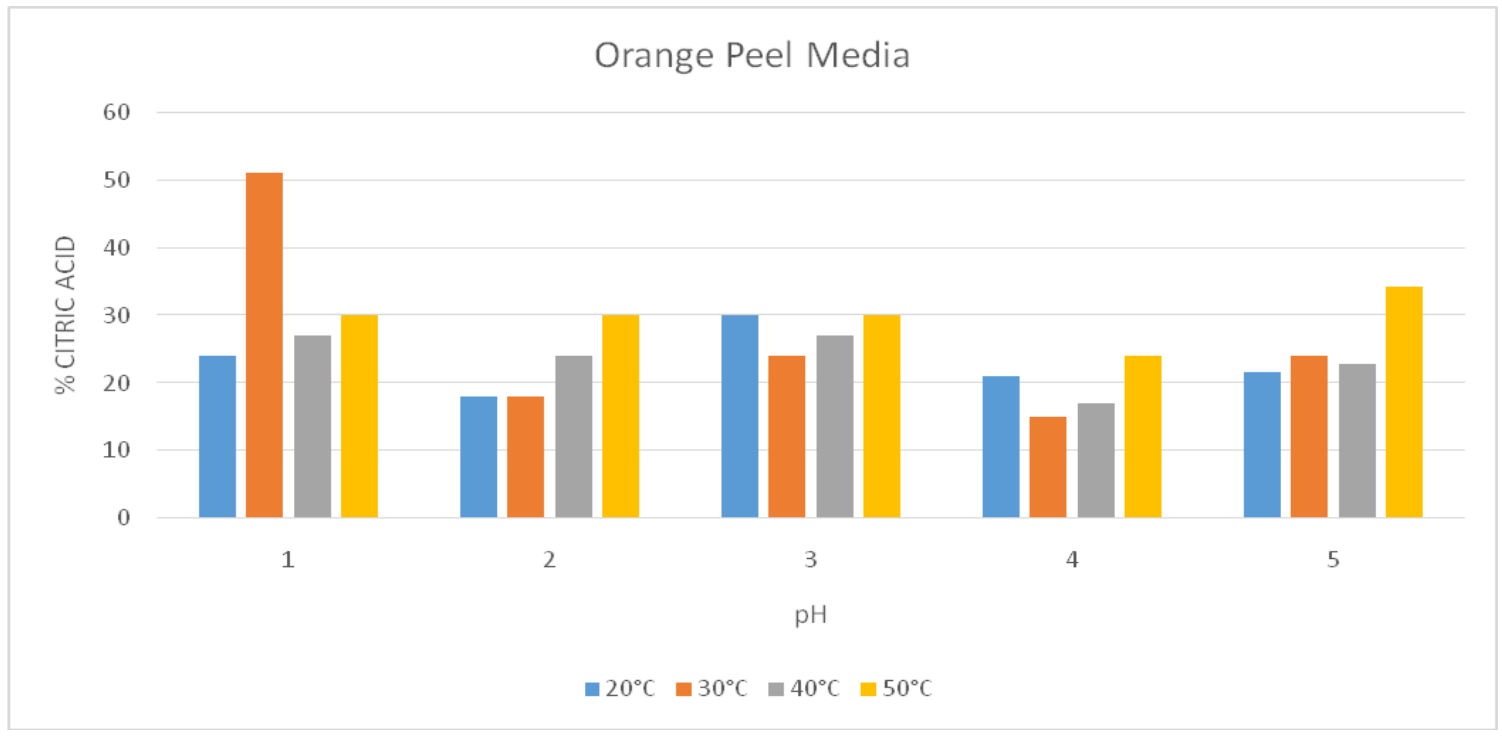


Table.7 \% Citric Acid produced on Czapek Dox Media at variable pH and Temperature.

\begin{tabular}{|c|c|c|c|}
\hline Media & pH & $\operatorname{Temp}\left({ }^{\circ} \mathrm{C}\right)$ & $\% \operatorname{acid}(w / v)$ \\
\hline \multirow{20}{*}{$\begin{array}{c}\text { Czapek } \\
\text { Dox Media }\end{array}$} & \multirow{4}{*}{1} & 20 & 13.2 \\
\hline & & 30 & 3.00 \\
\hline & & 40 & 14.6 \\
\hline & & 50 & 19.5 \\
\hline & \multirow{4}{*}{2} & 20 & 7.20 \\
\hline & & 30 & 4.40 \\
\hline & & 40 & 5.76 \\
\hline & & 50 & 5.40 \\
\hline & \multirow{4}{*}{3} & 20 & 13.0 \\
\hline & & 30 & 3.70 \\
\hline & & 40 & 8.40 \\
\hline & & 50 & 3.84 \\
\hline & \multirow{4}{*}{4} & 20 & 12.0 \\
\hline & & 30 & 5.70 \\
\hline & & 40 & 8.40 \\
\hline & & 50 & 3.90 \\
\hline & \multirow{4}{*}{5} & 20 & 11.8 \\
\hline & & 30 & 5.88 \\
\hline & & 40 & 6.90 \\
\hline & & 50 & 3.90 \\
\hline
\end{tabular}

Current findings of carried research work suggest cane molasses and orange peel media to be best sources for extraction of citric acid at $\mathrm{pH} 1$ and temperature $25^{\circ} \mathrm{C}$ to $30^{\circ} \mathrm{C}$ temperature. The conclusion of our work is coherent with the findings of other research groups which have suggested that lower the $\mathrm{pH}$ of media, better is the production percentage of citric acid on industrial scale.

\section{References}

Aboud-Zeid, A., Ashy, M.A. 1984. Production of citric acid: A review. Agric.Wastes, vol-9, p. 51-76

Ali, S., A. Rehman, I. Haq. 2003. Timecourse study of citrate fermentation by Aspergillus niger in stationary culture. Pak. J. Biol. Sci., 6: 331-333.
Ali, S., I. Haq., J. Iqbal. 2005. Effect of Low $\mathrm{pH}$ on continuous citric acid fermentation by Aspergillus niger. Pak. J. Bot., 37 (4):981-987.

Ali, S., IkramulHaq, Qader, M.A., Iqbal, J. 2002. Production of citric acid by $A$. niger using Cane molasses in stirred fermentor, Electronic J. Biotechnol., vol-5, no.3, p. 0717-3458.

Aravantinos-Zafiris, G., Tzia, C., Oreopoulou, V., Thomopoulos, C.D. 1994. Fermentation of orange processing wastes for citric acid production. J. Sci. Food Agric., 65, p.117-120

Doelger, W.P., S.C. Prescott. 1934. Citric acid fermentation. Ind. Eng. Chem., 26: 1142-1149.

Grewal, H.S., K.L. Kalra. 1995. Fungal production of citric acid. Biotechnol. $A d v$. vol 13 (2): 209-234 
Hang, Y.D., Woodams, E.E. 1985. Grape pomace: A novel substrate for microbial production of citric acid. Biotechnol Lett., 7: 253-254.

Hossain, M., Brooks, J.D., Maddox, I.S. 1984. The effect of the sugar source on citric acid production by Aspergillus niger. Appl. Microb. Biotechnol, 19, p. 393-39

JavedChehri, 2013. Factors affecting the growth of biomass of Aspergillus niger, Oric Publications, vol-1, no.1, p. 1-5.

Kundu, P., Panda, T., Majumdar, S.K., Guha, G., Bandyopadhyay, K.K. 1984. Pretreatment of Indian cane molasses for increased production of citric acid. Biotechnol. Bioeng, 26, p. 1114-1121.

Luciana, P.S., Vandenberghe, Carlos, S., Soccol, Ashok Pandey, Jean-Michel Lebeault, 1999. Microbial Production Of Citric acid, Brazilian Archives of Biol. Technol., vol-42, no.3.

Maharani, V., D., Reeta, A. Sundaramanickam, S., Vijaylakshmi, T., Balasubramaniam, 2014. Isolation and characterization of citric acid producing A. niger from spoiled coconut, Int. J. curr. Microbiol. Appl. Sci., vol-3, no.3: 700-705.

Majumdar, L., Ibrahim Khalil, Munshi M.K., K., Alam, Harun-Or-Rashid, Begum. R., Alam, N. 2010. Citric acid production by Aspergillus niger using Cane molasses and pumpkin as substrates, European J. Biol. Sci., vol-2(1):20792085.

Maria papagianne, 2007. Advances in citric acid fermentation by $A$. niger:
Biochemical aspects, membrane transport and modelling, J. Elsevier Science Direct, vol-25 p. 244-263.

NCBI. 2007. Aspergillus niger, Accessed August 23, 2007. <http://www.ncbi.nlm.nih.gov/Taxonom y/Browser/wwwtax.cgi?mode=Info\&id $=380704 \& l v l=3 \& p=$ mapview $\& p=$ has_li nkout $\& \mathrm{p}=$ blast_url\&p=genome_blast $\& 1$ in $=$ f\&keep $=1 \&$ srchmode $=1 \&$ unlock $>$

Rajoka, M.I., Ahmad, M.N., Shahid, R., Latif, F., Parvez, S. 1998. Citric acid production from sugar-cane molasses by cultures of Aspergillus niger. Biologia, vol. 44, no. 1, p. 241-253.

Richard, T., Tran, Yi Zhang, Dipendra Gyawali, Jian Yiang, 2009. Recent Development on Citric acid derived Biodegradable Elastomers, Recent Patent on Biomedical engineering, vol2, no.3, p. 216-227.

Schuster, E., Dunn-Coleman, N., Frisvad, J., van Dijck, P. "On the safety of Aspergillus niger - a review". Appl. Microbiol. Biotechnol., Volume 59. p. 426-435.

Singh, S.P., Verma, U.N., Kishore, M., Samdani, H.K. 1998. Effect of medium concentration on citric acid production by submerged fermentation. Orient $J$. Chem., 14, no. 1, p. 133-135.

Vandenberghe, L.P., S., Soccol, C.R. Pandey, A., Lebeault, J.M. 1999c. Solid-state fermentation for synthesis of citric acid by Aspergillus niger. Biores. Technol., (in press)

\section{How to cite this article:}

Pallavi Singh, Sadiya Draboo, Aishwarya Singh, Swapnil Chaturvedi, Swati Sharma and Pooja Verma. 2016. Citric Acid Production from Different Sources under Submerged Conditions using Aspergillus niger.Int.J.Curr.Microbiol.App.Sci. 5(5): 483-492. doi: http://dx.doi.org/10.20546/ijcmas.2016.505.050 